\title{
SZÉTHÚZÁS AZ ÖSSZETARTÁSBAN: AZ EURÓPAI UNIÓ BÍRÓSÁGÁNAK MUNKAVÁLLALÓKAT MEGKÜLÖNBÖZTETŐ JOGGYAKORLATA
}

\author{
István HERDON ${ }^{1}$
}

\begin{abstract}
In the field of employment law, the most common EU legal source is the directive. In most cases this legal source has binding force only for the Member States. The obligation of the Member State is to implement the EU directives into the national law. After the implementation procedure the claimant can refer to the national legal source instead of the original EU directive. However, there are some cases when the claimant can refer to and argue with the content of the original EU directive directly in front of the national courts and other national authorities. The aforementioned opportunity is the direct effect of the directives. The claimant can take advantage of this opportunity when the Member State violates the obligation of implementation. This study contains cases about the vertical direct effect of directives in the field of employment law.
\end{abstract}

\section{KEYWORDS}

EU labour law, employment law, directives, EU legal source, vertical direct effect, Court of Justice of the European Union (CJEU)

\section{BEVEZETÉS ÉS PROBLÉMAFELVETÉS}

Az Európai Unió valamennyi tagállamának a jogrendszerét a jogforrások két nagy csoportja az uniós jogforrások és a nemzeti jog - alkotja. Nincsen ez másképpen a munkajog terén sem. Sőt, a munkajog az egyik olyan jogterület, amelynek az uniós szabályozását a sokrétüség jellemzi, ugyanis munkajogi tartalommal rendelkező szabályokkal találkozhatunk a keményés a puha közösségi jogi normákban egyaránt. A közösségi jogban kemény jogként definiáljuk azon jogi aktusokat, amelyek kötelező erővel bírnak. Így az előbbihez tartoznak az alapító szerződések és az EU Alapjogi Kartája (a továbbiakban: Karta) - amelyek a kemény jogon belül az ún. elsődleges uniós jogot alkotják -, valamint a rendeleti, irányelvi és a határozati jogforrások, amelyek a másodlagos uniós jognak a részei. A puha joghoz leginkább az ajánlások, vélemények kapcsolhatók, amelyek nem bírnak kötelező erővel.[1]

A munkajog kötelező erővel bíró uniós szabályozása leginkább a másodlagos jogban, azon belül is az irányelvekben ölt testet.[2] Az irányelvi szabályozás lényege abban rejlik, hogy az uniós jogalkotás jellemzően pusztán csak egy keretet ad meg és annak végrehajtása a nemzeti jogalkotásra van bízva. Ez valójában azt jelenti, hogy az irányelv végrehajtása mint másodlagos uniós jogforrás kötelező a tagállamra nézve. A contrario ezen EUMSz. rendelkezés alapján az irányelv a tagállami szint alatt lévő magánszemélyeket nem kötelezi. Így tehát tisztán az irányelvi rendelkezésekre magánszemélyként - természetes vagy jogi személyként - hivatkozni föszabály szerint nem lehet, mivel azok tagállami átültető aktusokhoz vannak kötve. Az

\footnotetext{
${ }^{1}$ Herdon István, V. évfolyamos joghallgató, Környezetjogi és Munkajogi Tanszék tanszéki demonstrátora, Debreceni Egyetem Állam- és Jogtudományi Kar, istvan.herdon@gmail.com
} 
átültetés a tagállam kötelezettsége, így az irányelv kötelező uniós jogi norma a tagállamokra nézve.[3] Az átültető aktusok az irányelv rendelkezéseit az abban foglaltak szerint pontosíthatják, illetőleg hozzáigazíthatják az adott tagállami jogalkotáshoz és annak végrehajtáshoz.

A problémafelvetésem a köré összpontosul, hogy föszabály szerint az irányelvekre közvetlenül magánszemélyek nem alapíthatnak jogot, az érem másik oldalát tekintve pedig közvetlenül nem is kötelezhetik őket. Ezzel szemben az Európai Unió Bírósága (továbbiakban: EUB vagy Bíróság) jelentős számú esetben deklarálta, hogy vannak helyzetek, amikor irányelv - így a munkajogi tartalommal rendelkező irányelv is - hivatkozható magánszemély által, ha meghatározott feltételek teljesülnek. Az EUB több évtizedes gyakorlata fokozatosan kimunkálta ezt a feltételrendszert, amely kapcsán az irányelveknek közvetlen hatálya lehet. Megjegyzendő, hogy mivel ez a lehetőség az irányelv EUMSz. szerinti tartalmából nem következik, a Bíróságra hárult e feltételrendszer teljes kidolgozása. Ugyanakkor, ha megvizsgáljuk a Bíróság által kimunkált szempontrendszert és hozzávesszük a releváns joggyakorlatot, akkor az e tanulmány címében jelzett aggályok kikristályosodnak: az EUB különbséget tesz egyes munkavállalói csoportok között az uniós irányelvek közvetlen felhívhatósága terén. Ez a differenciáló joggyakorlat tartósnak látszik, a kérdés már csak az, hogy indokolt-e. A jelen tanulmányban elsők között szeretnék röviden kitérni az uniós jogforrások rendszerére és alapelveire, ezt követően pedig számba veszem az EUB által kimunkált feltételrendszert, különös tekintettel a tagállammal szembeni felhívhatóság problémakörére. Az utóbbi dilemma adja ugyanis a jelen tanulmány alapját, hiszen a bíróság által kimunkált ún. tagállom fogalom komoly kérdéseket vethet fel. Annyi bizonyos, hogy a jelen tanulmány végére látható lesz: az EUB megkülönböztető joggyakorlatot folytat a munkavállói és más hasonló jogállású személyek csoportjai között.

\section{Az Európai Unió jogforrásai és az ehhez kapcsolódó alapelvek}

Az uniós jogot elsőként feloszthatjuk kemény- és puha, valamint elsődleges- és másodlagos jogra.

A közösségi jogban kemény jogként definiáljuk azon jogi aktusokat, amelyek kötelező erővel bírnak. Így az előbbihez tartoznak az alapító szerződések és a Karta -amelyek a kemény jogon belül az ún. elsődleges uniós jogot -, valamint a rendeleti, irányelvi és a határozati jogforrások, amelyek a másodlagos uniós jogot képviselik. A puha joghoz leginkább az ajánlások, vélemények kapcsolhatók, amelyek nem kötelezők. Megjegyzendö, hogy az EU munkajoga amennyiben használhatok ilyen elnevezést - már az alapító szerződésekből levezethető. Az Unió ugyanis ,egy olyan, belső határok nélküli térség, amelyben a Szerződések rendelkezéseivel összhangban biztosított az áruk, a személyek, a szolgáltatások és a töke szabad mozgása".[4] Az EUMSz. a személyek szabad mozgásán túl később külön nevesíti a munkavállalás szabadságát. Az EU munkajogi két fő területtel foglalkozik igazán, amelyek a munkakörülmények, valamint a munkavállalók tájékoztatása és a velük folyó konzultáció. Ezen szabályozási területek biztosítják, hogy az tagállamok és a vállalkozások tisztességesen versengjenek egymással, és a versenyben ne a munkajogi normák kerüljenek háttérbe a közvetlen gazdasági érdekekkel szemben. Mindezek - mint ismeretes - leggyakrabban irányelvi szinten jelennek meg.

Kiemelendő, hogy bár a tételes uniós szintű munkajogi szabályozás a másodlagos jogforrások - így különösen a fent említett irányelvekben - képében ölt testet, az elsődleges jogforrások szerepe elvitathatatlan. Ugyanakkor azt is fontos hangsúlyozni, hogy mindezek mellett általánosságban az uniós jog értelmezése a Bíróság a feladata, így amennyiben az uniós jog tartalmával összefüggésben kérdés merül fel, arra autentikus válasz a Bíróságól remélhető. Ennek keretében az EUB hatáskörrel rendelkezik az alapító szerződések értelmezése, valamint 
az uniós intézmények, szervek vagy hivatalok jogi aktusainak érvényessége és értelmezése terén.

Különös jelentőséggel bír az EUB előtti előzetes döntéshozatali eljárás. Ennek keretében az uniós jog feljogosítja a tagállami bíróságot, hogy az előtte folyó ügyben felmerülő uniós jogi norma értelmezésével vagy érvényességével kapcsolatban kérdésével az EUB-hoz forduljon és attól kötelező érvényü állásfoglalást kérjen. Ennek a jelentősége nemcsak az adott ügyben merül fel, hanem akkor is, amikor az adott uniós jogi normának az értelmezése vagy érvényessége más ügyben kérdésessé válik. Így ugyanis a nyilvános, előzetes döntéshozatali eljárásban született EUB által adott állásfoglalások unió-szerte elősegítik az egységes jogalkalmazást. A jogintézmény elvitathatatlan jelentősége emellett abban áll, hogy olyan esetekben, amikor tagállami bíróság határozatai ellen a nemzeti jog értelmében nincs jogorvoslati lehetőség, e bíróság köteles a Bírósághoz fordulni.

Az előbb felvázoltak - ideértve különösen a Bíróság tevékenységét - mellőzhetetlenek ahhoz, hogy a következőkben a jogforrásokra jellemző két fontos alapelvvel foglalkozzak, amelyek az elsőbbség elve és a közvetlen hatály elve.

Az elsőbbség elve legáltalánosabban azt jelenti, hogy amennyiben egy tagállami jogszabályi rendelkezés és a közvetlen hatályú - amelyet lentebb kifejtek majd - uniós jogszabály rendelkezése egymással ütközik, akkor az uniós jognak nem megfelelő tagállami jog helyett a vonatkozó uniós jogi rendelkezést kell alkalmazni. Jogalkalmazási eljárásban tehát ilyen kollízió esetén a nemzeti bíróságnak félre kell tennie az uniós joggal ellentétes, annak nem megfelelő tagállami jogot és az uniós jogot kell alkalmaznia. Ennek az alapelvnek a rendeltetése az is, hogy a tagállamok egységesen kezeljék az uniós jogot, hiszen ennek híján a tagállami jogalkotás torzítaná az uniós jog tartalmát, amely különböző jogalkalmazást eredményezne a közösségen belül. Az elsőbbség elve jogalkotás során is megfelelően irányadó úgy, hogy uniós joggal ellentétes tagállami norma nem alkotható.[5]

Az elsőbbség elvénél kifejtettek szerint azon uniós jogi normák bírnak az elsőbbség elvéhez füződő jogkövetkezményekkel, amelyeknek közvetlen hatálya van. Az uniós legtöbb esetben a tagállamokat és szerveit kötélezi. A közvetlen hatály fogalma viszont azt jelenti, hogy a magánfelek az adott közvetlen hatállyal bíró uniós jogi normát felhívhatják a tagállami bíróság előtt folyamatban lévő eljárás során.[6] Absztraktabb megfogalmazással élve ez az elv azt foglalja magában, hogy egy uniós jogi rendelkezés alanyi jogok és kötelezettségek forrása lehet és ez a jogalkalmazó szervek előtt kikényszeríthető.[7] CSÁSZÁR kiemeli, hogy ez lényegében azt takarja, hogy a bírósági eljárásban a petitum jogalapja maga a közvetlenül hatályos uniós rendelkezés. A közvetlen hatályon belül két fogalmat szükséges rögtön tisztázni. A közvetlen hatály érvényesülhet vertikális és horizontális viszonylatban egyaránt. Az előbbi esetén a tagállam és magánszemély viszonylatában keletkeztet az uniós norma olyan jogot vagy kötelezettséget, amely tagállami bíróság előtt felhívható egy magánszemély. Az utóbbi esetben pedig magánszemélyek viszonylatában (is) érvényesül ugyanez.[8]

\section{Az irányelvek közvetlen hatálya}

Az irányelvek eredeti rendeltetésük szerint tehát nemzeti átültető aktust igénylő uniós jogforrások, amelyek nagyban hozzájárul a tagállamok közötti jogharmonizációhoz. Az alapeset mindenképpen az, hogy e közösségi normák nem rendelkeznek közvetlen hatállyal. Ugyanakkor az 1970-es évektől az EUB ítélkezése folytán megszületett az irányelvekkel összefüggésben kimondott közvetlen hatály doktrínája, amely - CsÁszÁR szavaival élve „örökzöld” témája az uniós joggal foglalkozó jogirodalomnak. Elsősorban a közösségi jog hatékony érvényesülése és az irányelv kötelező jellege ösztönözte arra a Bíróságot, hogy ebben az esetekben is deklarálja ezt az elvet, persze bizonyos feltételek teljesülése esetén.[9]

A közvetlen hatály elve az Európai Unió jogforrásai kapcsán két kontextusban emelhető ki. Egyfelől beszélhetünk vertikális közvetlen hatályról, amely azt jelenti, hogy az adott jogforrást 
- jelen esetben egy irányelvet - magánfelek felhívhatnak a tagállam szemben bírósági vagy hatósági eljárásban. Másfelöl pedig horizontális közvetlen hatály is létezik, am azt jelenti, hogy az adott uniós jogforrást a magánfelek egymással szemben is felhívhatják. Ha megnézzük az EUB irányelvekre vonatkozó joggyakorlatát, akkor megállapítható, hogy EUB csak a vertikális közvetlen hatály kimondásáig ment el. Így a horizontális közvetlen hatály az irányelvek esetén kizárt.

\section{A vertikális közvetlen hatály}

A kiindulópont az, hogy egy irányelv közvetlen hatályának megállapítására éppen egy munkajoggal kapcsolatos esetben került sor, méghozzá a már klasszikus tankönyvi példává vált Van Duyn-ügyben. A tényállás lényege röviden, hogy a Van Duyn holland állampolgárságú felperes az Egyesült Királyságban szertett volna munkát vállalni, ám a brit hatóságok megtagadták az országba való belépését. A szabad munkavállalás jogát jelenleg - érdemben változatan tartalommal - az EMSz. 46. cikke deklarálja. E szabadságot derogálni csak az alapító szerződés felhatalmazása alapján született - akkor hatályos - 64/221/EGK irányelv alapján bevezetett, illetve átültetett közrendre történő hivatkozással lehetett. Az irányelv rendelkezéséből kitünik, hogy a közrendi, illetve közbiztonsági indokok alapján hozott intézkedések kizárólag az érintett személy viselkedésén alapulhatnak. A Bíróság megállapította, hogy a rendelkezés olyan kötelezettséget határoz meg, amely nem tartalmaz semmilyen feltételt, és a tagállamok részéről semmilyen jogi - így átültető - aktust nem igényel. A Bíróság azt a megállapítást tette, hogy a „,(...) közösség hatóságai irányelvekben kötelezték a tagállamokat arra, hogy meghatározott magatartást kövessenek, egy ilyen jogi aktus hatékony érvényesülése sérülne, ha a jogalanyok nem hivatkozhatnának rá a bíróságok elött”. Emellett kimondta, hogy „minden egyes esetben meg kell vizsgálni, hogy a szóban forgó rendelkezés természete, rendszere és kifejezései alapján alkalmas-e közvetlen hatály kiváltására a tagállamok és a magánszemélyek közötti jogviszonyokban".[10]

A fenti, különösen jelentős döntésböl az alábbi konklúziók vonhatók le. Az irányelvek rendelkez(het)nek közvetlen hatállyal, de ez nem érvényesülhet automatikusan a teljes irányelvre, annak minden rendelkezésére nézve. Azt, hogy mely normák hívhatók fel közvetlenül, minden esetben külön meg kell vizsgálni. A közvetlen hatály csak vertikálisan, tagállam és magánszemély viszonylatában merülhet fel. E mellett a későbbiekben egyre jelentősebbé váló kritériumok egyike, a feltétel nélküliség, is kiolvasható az ítéletből.

\section{A vertikális közvetlen hatály teljesülésének feltételrendszere ${ }^{2}$}

Ahogyan korábban említettem a Bíróság következetes gyakorlata tartja magát ahhoz, hogy csak azon irányelveknek fogadja el a közvetlen hatályát, amelyek feltétlenek és kellően pontosak.[11]

Ugyanakkor e két fogalomnak a jelentéstartalma eltérhet attól, mint amire egyes jogértelmező szervek vagy személyek gondolnak. A Bíróság joggyakorlata szerint valamely rendelkezés akkor feltétlen, ,ha olyan kötelezettséget fogalmaz meg, amely nem tartalmaz feltételt, és nem függ - a végrehajtásában vagy hatályában - az Unió intézményeinek vagy a tagállamoknak semmilyen jogi aktusától”. Egy irányelvi rendelkezés ,akkor kellően pontos ahhoz, hogy egy jogalany hivatkozhasson rá, és a bíróság alkalmazhassa, ha egyértelmüen fogalmaz meg valamely kötelezettséget". Ugyanakkor az elöbbi két kritérium abban az esetben is teljesül, ha az irányelvi rendelkezés nemzeti a jogszabályra vagy gyakorlatra utal, valamint bizonyos mérlegelési mozgásteret hagy a tagállamok számára a végrehajtási módozatok elfogadása

\footnotetext{
2 A fenti feltételrendszer, valamint az ezzel kapcsolatos konklúziók HERDON István: Munkavállalók közötti különbségtétel az Európai Unió Bíróságának joggyakorlatában In: Szűcs Lászlóné Siska Katalin-Talabos, Dávidné Lukács Nikolett (szerk.): A jog tudománya, a mindennapok joga IV. címü tanulmánykötetbe leírtak alapján kerültek kifejtésre.
} 
során. Az irányelvi rendelkezés feltétlen jellegét az olyan tény sem kérdőjelezi meg, amely valamely juttatást nemzeti jogszabályok szerint meghatározott esetleges maximum függvényében ír elő. Ez nyilván tagállamonként eltérő eredményt jelenthet, ám nem akadálya a közvetlen hatálynak.[12] A pontos és feltétlen rendelkezés kritériuma abban az esetben is teljesül, ha az irányelv csak valamilyen minimum védelmi szintet határoz meg, méghozzá olyat, amelyet mindenképpen garantálni szükséges, ezen felül pedig természetesen már a tagállamok diszkrecionális joga a magasabb védelmi szint meghatározása.[13] A védelmi szinttel összefüggésben álláspontom szerint abban az esetben is megállja a helyét a közvetlen hatály, ha az uniós irányelv olyan rendelkezést tartalmaz, amely például elöírja, hogy az irányelv végrehajtása nem vezethet a munkavállalók számára biztosított - már meglévő - általános védelem szintjének csökkenéséhez.[14]

A közvetlen hatály megállapítása ugyanakkor nem jelent egyben garanciát arra, hogy az arra hivatkozó személynek a kereseti kérelme megalapozott legyen. Leginkább úgy közelíthető meg a kérdés, hogy ha a közvetlen hatály feltételei fennállnak, akkor a tagállami bíróság vagy más hatóság ténylegesen és érdemben közvetlenül jogot és kötelezettséget alapíthat rá, amely abban is megmutatkozhat, hogy a bíróság a közvetlenül hatályos irányelvre alapított petitumát elutasítja és deklarálja a nemzeti rendelkezés uniós jogi komformitását - így a munkáltató jogszerü intézkedését -, kötelezve ezzel a munkavállalót ennek betartására.

Az irányelvek vertikális közvetlen hatállyal rendelkeznek, amely azt jelenti, hogy azok állam és magánfél viszonylatában hívhatók fel. Az előbbi kizárólag egy irányba teljesülhet, így csak a magánfél hívhatja fel azt a tagállammal szemben.

E kapcsán kiemelkedő joggyakorlati forrás a Marshall-ügy, amely a foglalkoztatáspolitika terén deklarált olyan eredményeket, amelyek hatása később más jogterületeken is megmutatkozott az ítélkezésben. Az ügyben a felperes azért fordult bírósághoz, mert 62 éves nő létére munkáltatója szemben azzal, hogy a férfiakat 65 éves korukig alkalmazta, a nőkre 60 éves korhatárt állapított meg. A munkáltatója egy hatóság - „authority” - volt. Ez egyébként megfelelt az állami nyugdíjkorhatárnak. A perben a felperes hivatkozott a férfiak és nők egyenlő bánásmódját deklaráló akkor hatályos 76/207/EGK irányelvre. A perben eljáró tagállami bíróság előzetes döntéshozatali eljárásban kérdésként fogalmazta meg az EUB felé, hogy a fenti korhatárkülönbséget kimondó nemzeti szabályozás összhangban van-e a citált irányelvvel. A Bíróság megállapította, hogy a nyugdíjkorhatárra vonatkozó nemzeti rendelkezés sérti a hivatkozott irányelvet. Ebből kifolyólag - természetesen azt követően, hogy megállapította az anyagi jogi kritériumok teljesülését - deklarálta továbbá, hogy ,ahol egy törvényes eljárásban szereplő személy egy irányelvre támaszkodhat mintegy az állam ellenében, ezt megteheti arra való tekintet nélkül, hogy az utóbbi milyen minőségben jár el, akár mint munkaadó, akár mint állami hatóság."[15] Ennek az az oka, hogy meg kell akadályozni, hogy állam bármiféle előnyre tegyen szert akkor, ha nem vagy nem megfelelően ültet át egy irányelvet, ahogyan jelen esetben nem biztosította a nemek közötti egyenlő bánásmódot az irányelv értelmében. Az állam tehát a saját mulasztásából előnyt nem kovácsolhat, így VÁRNAY megjegyzi, hogy a magánjogi jogviszonyok alanyaként is közvetlenül kötelezettség származhat az irányelvekböl az állam hátrányára. Az alperesi oldalon megjelenő hatóság az Egyesült Királyság nevében járt el, ez utóbbi azt az észrevételt tette, hogy a Bíróság ezen megoldása önkényes és tisztességtelen megkülönböztetést eredményez a köz- és magánszféra dolgozói között.[16]

Az állammal szemben tehát egyes, közvetlen hatállyal rendelkező irányelvek felhívhatók tekintet nélkül arra, hogy az munkáltatóként vagy éppen közhatóságként jár el. Mivel tanulmányom leginkább munkajogi témakört ölel fel, ezért az elöbbi státusz bír jelentőséggel. Munkáltatóként pedig akkor képzelhető el az állam, ha mint munkaviszony - illetve ilyen jellegü, ennek a minősítő jegyeit magán hordozó, foglalkoztatásra irányuló jogviszony alanyaként jelenik meg. Értelemszerüen vele szemben a foglalkoztatottak, illetve kollektívájuk hívhatja fel valamely közvetlenül hatályos irányelvi rendelkezést. A közvetlen hatály oly 
módon történő kimondásával, amely az EUMSz. 288. cikkéből nem vezethető, már a munkajogi szakirodalom is foglalkozott. Ennek keretében a jogirodalom megjegyzi továbbá, hogy az irányelv közvetlen hatálya kimondásának bírói gyakorlattá való formálódása esetén az irányelv a ,jogviszonyok szélesebb spektrumán nyerhetne alkalmazást külön tagállami jogi aktus nélkül’.[17]

\section{Az állami szerv fogalma, avagy milyen szervnél foglalkoztatott személyek hivatkozhatnak közvetlenül az irányelvekre?}

A tanulmányom témájának leginkább vitaindító szándékú része az alábbiakban kerül kifejtésre. Az irányelvek közvetlen felhívhatósága kapcsán egyes esetekben minden kritérium rendelkezik valamilyen bizonytalan ponttal. Ugyanakkor álláspontom szerint annak, hogy az irányelvek rendelkezései közvetlenül kivel szemben hívhatók fel, nem is a bizonytalansága, hanem inkább az ítélkezési gyakorlatban testet öltő eredménye a szembeötlö. A Marshall-ügy kapcsán az elöbb már bemutattam az állami szerv ,,alapfogalmát”.

Az állami szervek közé tartoznak értelemszerủen a nemzeti hatóságok. Hazánkban a hatóság fogalmát az általános közigazgatási rendtartásról szóló 2016. évi CL. törvény (Ákr.) rögzíti. A definícióból egy fontos elem is kitünik, amelyet egyébként már az EUB is egy nem munkajogi, mégis jelentős döntésben [18] deklarált, ez pedig az önkormányzattal összefüggő kérdések. Az előbbi ügyre hivatkozva állapítja meg a Bíróság a 2003/88 EK irányelv maximális átlagos heti munkaidőt szabályozó passzusának közvetlen hatályát. Így az EUB rögzíti, hogy a hivatkozott irányelvvel ellentétes az olyan nemzeti szabályozás, amely lehetővé teszi az állami szektorban müködő munkáltató számára, hogy a beavatkozó egységnél tüzoltóként foglalkoztatott munkavállalót kötelezően másik egységhez helyezze át azzal az indokkal, hogy az az említett rendelkezésben előírt maximális átlagos heti munkaidő említett beavatkozó egységnél való tiszteletben tartását kérte. E tekintetben a tagállamokat olyan eredménykötelezettség terhelte amely világos, feltétlen és pontos volt -, hogy az irányelv implementációját követően a túlórát is magában foglaló átlagos heti munkaidő nem haladhatja meg a 48 órát. Az állami szerv fogalma pedig úgy merült fel, hogy a tüzoltó városi - önkormányzati - szinten került alkalmazásra, amellyel összefüggésben a Bíróság egyértelműen állást foglalt: ,a nemzeti bíróság és a közigazgatási szervek, beleértve a decentralizált hatóságokat is, kötelesek teljes egészében alkalmazni az uniós jogot, (...) szükség esetén mellőzve a nemzeti jog azon rendelkezéseinek alkalmazását, amelyek az előbbivel ellentétesek". [19]

Bár ez sokak szerint mindenképpen egy kitágított fogalomértelmezés, álláspontom szerint nem az, mivel az állam részét képezik az olyan közigazgatási egységek is, amely egyébként más államháztartási alrendszerbe sorolandók, vagyis tipikusan az önkormányzatok is.[20] A hatályos magyar szabályozás értelmében tehát ide sorolnám az államháztartásról szóló 2011. évi CXCV. törvény (Áht.) 3. §-a szerinti állami és önkormányzati alrendszerekbe tartozó költségvetési szerveket, az ide sorolt köztestületeket, nemzeti önkormányzatot, önkormányzati társulást, térségi fejlesztési tanács és minden, az előbb felsoroltak valamelyikének irányítása alá tartozó költségvetési szervet. Az előbbit alátámasztására egy olyan döntés mutatok be, amely alapján véleményen szerint is igen kiszélesedik az irányelvek közvetlen felhívhatósága. Az eset alapját az 1990/70/EK irányelv egy szakasza adta, amely értelmében általánosan megfogalmazva a foglalkoztatási feltételek szempontjából a határozott időre foglalkoztatott munkavállalók nem részesülhetnek kedvezőtlenebb bánásmódban, mint a klasszikus munkaviszonyban foglalkoztatottak. A jogvita tárgyát a kedvezőtlenebb bánásmód okozta kompenzáció terén, amely kapcsán az EUB azt rögzítette, hogy a „,foglalkoztatási feltételek fogalma magában foglalja azt a kártérítést, amelyet a munkáltatónak a munkavállaló részére kell fizetnie határozott idő munkaszerződésében való jogellenes kikötése miatt, továbbá ezen irányelvi kikötés közvetlen hatállyal bír. Az eset jelentősége, hogy a közvetlen hatály eljárásjogi feltételével, az állam fogalmával kapcsolatban a Bíróság hosszú okfejtésbe bocsátkozott. 
Idézve a tankönyvekből jól ismert Foster és társai ügyben hozott döntését, rögzítette, hogy ha valamely irányelv rendelkezéseire közvetlenül hivatkozni lehet, ezt meg lehet tenni olyan szervezetekkel szemben is, amelyek ,jogi formájuktól függetlenül, hatóság döntése alapján és ellenőrzése mellett közszolgáltatást nyújtanak, és amelyeknek evégett a magánszemélyek közötti jogviszonyokra alkalmazandó szabályokból eredökhez képest lényegesen több jogosítványuk van”. Az állami szerv kapcsán - amint azt a Bíróság kimondta - ,a közösségi irányelveken alapuló kötelezettségek kötelezik azokat a szervezeteket vagy szerveket, amelyek valamely közhatalmi szerv vagy az állam felügyelete, illetve ellenőrzése alá tartoznak". A Bíróság az előbb citált absztrakt feltételrendszer az előtte fekvő ügyben konkretizálta. A Poste Italiane -azaz az olasz posta - tulajdonosa 100\%-ban az olasz állam, az ottani számvevőszéki intézmény gyakorol felügyeletet felette, amelynek egyik tagja az igazgatótanács tagja is. A vállalatot különböző ágazatokban, ideértve a postai ágazatot, egyetemes szolgáltatások nyújtásával bízta meg a minisztérium, aki az általános felügyeleti és számviteli ellenőrzési jogkört gyakorolja, költségvetése az állami költségvetéshez kapcsolódik, veszteségeit fedezi. A Bíróság az ügyben óvatosan, de végül megállapíthatónak vélte az elöbbi körülmények összességére tekintettel azt, hogy a hivatkozott vállalattal szemben felhívható az irányelv, mert az az állam fogalmi körébe esik.[21]

Jól észlelhető, hogy az EUB törekedett e döntésben az állam fogalmi kiterjesztését minél jobban tisztázni, hivatkozva olyan, más döntésekben szerepelö körülményeket is- azok teljességében , amelyeknek itt nem feltétlenül van szerepük. Ha sorra vesszük a fenti feltételeket, úgy egy tág halmazt kapunk azzal kapcsolatban tehát, hogy milyen esetben hivatkozhat a munkavállaló a munkáltatójával szemben egy irányelvi rendelkezésre.

Túllépve a közvetlen államiságon, ide sorolható az olyan munkáltató, amely hatóság döntése alapján és ellenőrzése mellett közszolgáltatást nyújt és magánszemélyekhez képest többletjogosítványai vannak, tekintet nélkül a jogi formára. E meghatározás véleményem szerint nagyon széles körre kiterjedő, és szükebb értelme mindenképpen társasági jogi kategória. Ennek értelmében minden közszolgáltatást (is) végző társaság ide sorolható a társasági formától függetlenül, ami megfelel a fenti feltételeknek. Ezek legtöbb esetben - így hazánkban is - az állam által alapított és tulajdonolt gazdasági társaságok. A hatóság rendelkezése alapján véleményem szerint különösen az engedély vagy elöírás értendö, míg ellenőrzés alatt mind társasági jogi, mind közhatalmi ellenőrzést kell értenünk. Az előbbi a tulajdonosi jogok gyakorlásával valósulhat meg, amelyre a Bíróság is utalt az olasz posta kapcsán, amely szerint az olasz állam a 100\% tulajdonosa. Így véleményem szerint megvalósul az ellenőrzés, ha az állam legalább többségi tulajdonos egy társaságban vagy olyan jogosítványokkal rendelkezik, amelyek őt többségnek megfelelő befolyásra jogosítják fel. Amennyiben ezen körülményeknek nem felel meg a magánjogi ellenőrzés elnevezés, tartalmi értelemben nincs változás, hiszen az EUB is deklarálta, hogy a tulajdonosi összetétel egy kiemelt szempont az államhoz való kapcsolódásnak a vizsgálata során.[22] A közszolgáltatás definíciója is rendkívül tág határok között mozog, azok mindegyikének felsorolása meghaladja a jelen tanulmány kereteit. Ide sorolható ugyanakkor a honvédelem, rendvédelem és közbiztonság, környezetvédelem, egyes gazdasági funkciók, egészségügy, oktatás, szociális igazgatás, rekreáció, kultúra és vallás területen kifejtett egyes tevékenységek. Látni kell ugyanakkor, hogy a közszolgáltatások nyújtására közel sem csak állami hátterü társaságok lehetnek képesek és jogosultak. Így akár kötelmi jogviszonyok is e körbe tartozhatnak, mint például az állami, valamint önkormányzati tulajdon hatékony müködtetésének, valamint a kizárólagosan az állam vagy az önkormányzat hatáskörébe utalt tevékenységek gyakorlásának koncessziós szerződés alapján való átengedése. Ez ugyanakkor megalapozottan vita tárgya lehet, hiszen föleg a koncesszióköteles tevékenységek terén jelen vannak olyanok - például dohánykereskedelem -, amelyek indokolatlanul túlmutatnak a Bíróság által megadott érvrendszeren. Egyebekben viszont teljesülnek az EUB által meghatározott kritériumok, hiszen 
a koncesszióadónak a magánjogi eszközökön túl közjogi, közhatalmi eszközrendszer is a birtokában van a szerződés teljesítésének az ellenörzésére vagy éppen a kikényszerítésére.[23] Úgy vélem, hogy további kutatómunkát igényelne annak a kérdésnek a megválaszolása, hogy a tagállam fogalma milyen határok között értelmezhető pontosan. Elöre vetíthető, hogy ez a határ sokkal tágabb, mint elsőre gondolnánk. A tagállam fogalmi elemeit ugyanis a közigazgatás és az államháztartás több szintjének figyelembevételével kell megközelíteni. Az előbbiek kapcsán viszont úgy gondolom, hogy sikerült betekintést adni abba a dilemmába, amelyet a tanulmány címében is felvázoltam

\section{ZÁRÓ GONDOLATOK}

Végezetül, tanulmányomból kitünik, hogy a munkajogi irányelvek jóval részletesebb vizsgálatot érdemelnek, mint amilyenben eddig részsültek. Az ugyanis, hogy ezen irányelvek bizonyos esetekben közvetlen hatállyal rendelkeznek, kiszélesítik a nemzeti jogforrási rendszert is. Ugyanakkor az további gondolkodásra ösztönözhet, hogy milyen mértékben bírhat jelentőséggel az irányelvek közvetlen hatálya a munkajogban. Fontos leszögezni, hogy alapvető kritériuma a közvetlen felhívhatóságnak, hogy az irányelvi rendelkezés kellően pontos és feltétel nélküli legyen, valamint, hogy a tagállam elmulassza annak megfelelő implementációját a nemzeti jogba. Amennyiben az előbbi kondíciók teljesültek, az irányelv felhívható egy tagállam-magánfél közötti jogvitában, de csak a magánfél által a tagállammal szemben. Viszont a felvázolt téma legnagyobb dilemmáját az adja, hogy a tagállam fogalma mennyire szélesíthető ki a közfelfogás szerinti állam fogalomhoz képest. A tanulmányban citált esetekkel megkíséreltem rámutatni arra, hogy olyan szervek által foglalkoztatott személyek is hivatkozhatnak közvetlenül az irányelvre, ahol ezt első megfontolásra lehetetlennek tartanánk. Zárásként pedig kiemelem, hogy ennek lényege abban rejlik, hogy szélesebb tagállam-fogalom mellett szélesebb munkavállalói kör hivatkozhat közvetlenül az irányelvekre a tagállammal mint munkáltatóval szemben. Ezzel pedig visszajutottunk a tanulmány címében rögzített megállapításhoz: az EUB az irányelvek vertikális közvetlen hatályának kimondásával a munkavállalók egyes csoportjai között - azok munkáltatója szerint - megkülönböztető joggyakorlatot folytat.

\section{KÖSZÖNETNYILVÁNÍTÁS}

A tanulmány szerzője ezúton is köszönetét fejezi ki Dr. Zaccaria Márton Leó adjunktusnak az elöremutató tanácsaiért és önzetlen segítségéért.
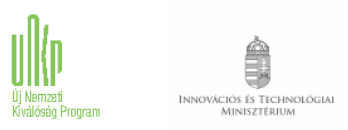

A jelen tanulmány és az ennek alapjául szolgáló kutatás az Új Nemzeti Kiválóság Program, az Innovációs és Technológiai Minisztérium, valamint a Nemzeti Kutatási, Fejlesztési és Innovációs Alap által támogatott, „Nehéz jogi esetek az Európai Unió munkajogában" című pályázat keretében valósult meg. Pályázati azonosító: ÚNKP-20-2-I-DE269

\section{IRODALOMJEGYZÉK}

[1] ANGYAL, Zoltán, ASZTALOS Zsófia, FAZEKAS, Judit, GYENEY, Laura METZINGER, Péter, OSZTOVITS, András, SZABÓ, Marcel (szerk.: OSZTOVITS, András). EU-jog. Budapest : Hvg-Orac Lap- és Könyvkiadó Kft., 2015., 174 p. ISBN: 9789632582788 
[2] PRUGBERGER, Tamás, NÁDAS, György. Európai és magyar összehasonlitó munka- és közszolgálati jog. Budapest : Wolters Kluwer, 2014., 50 p. ISBN 9789632954059

[3] EUMSz. 288. cikk

[4] EUMSz. 26. cikk

[5] BLUTMAN, László. Az Európai Unió joga a gyakorlatban. Budapest : Hvg-Orac Lap- és Könyvkiadó Kft., 2010. 332-333 p.; 336-337 p. ISBN 9789632580906

[6] VÁRNAY, Ernő, PAPP, Mónika. Az Európai Unió joga. Budapest : Wolters Kluwer, 2015. 301-302 p. ISBN 9789632955261

[7] BLUTMAN: i. m. 344 p.

[8] CSÁSZÁR Mátyás: Az irányelvek közvetlen hatálya. In: Acta Juridica et Politica, Szeged, 1998; http://acta.bibl.u-szeged.hu/37769/1/juridpol_054_fasc_004.pdf (2020. 08. 11.), $37 \mathrm{p}$.

[9] CSÁSZÁR. i. m. 39 p. ISSN 1787-3223

[10] 41/47. Van Duyn kontra Home Office

[11] C-17/17 - Hampshire

[12] C-194/08 - Gassmayr

[13] C-168/18 - Pensions-Sicherungs-Verein

[14] Lásd például: 2003/88/EK irányelv 23. cikk

[15] C-271/91 - Marshall

[16] VÁRNAY, PAPP. i.m. 325 p.

[17] NÁDAS, György, RAB, Henriett, SIPKA, Péter, ZACCARIA, Márton Leó. Az egyenlő foglalkoztatás követelménye a változó munkajogi elvárásokat tükrözö HR tendenciák keretei között. Budapest : Hvg-Orac Lap- és Könyvkiadó Kft., 2018., 61 p. ISBN 9789632583785

[18] C-103/88 - Fratelli Costanzo kontra Comune di Milano

[19] C-243/09 Günter Fuß kontra Stadt Halle

[20] HORVÁTH, M. Tamás, VARGA, Judit. Államháztartási erőforrások joga. BudapestDebrecen : Dialog Campus - Debreceni Egyetemi Kiadó, 2019., https://dupress.unideb.hu/termek/allamhaztartasi-eroforrasok-joga-e-konyv/ (2020. 08. 12.) 101 p. ISBN 978-963-531-032-6 (e-könyv)

[21] Nihls Wahl fötanácsnoki indítvány C-361/12 Carmela Carratù kontra Poste Italiane SpA

[22] C-361/12 Carmela Carratù kontra Poste Italiane SpA

[23] PAPP, Tekla. A koncesszió néhány társasági jogi vetülete. http://jesz.ajk.elte.hu/papp8.html (2020. 08. 14.) 